\title{
Economic and Legal Aspects of the Network Readiness of the Enterprises in Ukraine in the Context of Business Improving
}

\author{
OKSANA ZYBAREVA ${ }^{1}$, IRYNA KRAVCHUK², YAROSLAV PUSHAK ${ }^{3}$, \\ LIUDMYLA VERBIVSKA ${ }^{* 4}$, OLENA MAKEIEVA ${ }^{5}$ \\ ${ }^{1,2,4}$ Department of Entrepreneurship, Trade and Stock Market Operations, Yurii Fedkovych Chernivtsi National \\ University, UKRAINE. E-mail: I.verbivska@chnu.edu.ua \\ ${ }^{3}$ Department of Economy and Economic Security, Lviv State University of Internal Affairs, UKRAINE. \\ ${ }^{5}$ Department of Theory and History of State and Law, National Aviation University, UKRAINE.
}

\begin{abstract}
In this paper, the network readiness of the enterprises in Ukraine has been analyzed. National statistics data and international indices were used to measure and characterize fundamental changes in Ukraine at the economic and business levels. These changes are influenced by modern information technologies and new global information society tendencies. Indicators used to measure the network readiness of the enterprises were examined. Obtained results show positive dynamic improvement and simplification of enterprise activities under network economy growth in Ukraine. The detailed examination of individual indicators confirmed infrastructure and availability of digital content and prevalence of the business and innovation environment over the network economy's actual enterprise performance in 2018.

An integral indicator was used to measure the level of actual use of information and communication technologies, the implementation of innovations, automated data exchange by national enterprises, and network readiness. The integral indicator of the enterprises' network readiness is a comprehensive summary of 46 components were grouped by authors into the following blocks: infrastructure and availability of digital content; business and innovation environment; business exploitation.

The analysis of the selected block of indicators for 2010-2018 showed positive network readiness dynamics. The gap between the enterprises' network readiness at the regional and national levels was measured by calculating the distance between the network vector of a particular region and the average values in Ukraine. In 2018, the length of the network vector $A j$ was 57.27. Of the 622 enterprises surveyed, almost $94 \%$ used computers. Among the studied enterprises, a large proportion used the Internet to carry out banking operations and automated data exchange, receive tax forms, send or forward completed forms.

A negative trend towards an increase in the gap between information and communication technologies at the regional and national levels has been revealed. The studied indices of the enterprises' network readiness in Ukraine enabled us to measure the level of digital infrastructure, business climate, business opportunities provided to some extent by information and communication technologies and the Internet, facilitating business operations and their quantity. The authors selected indices related to network readiness, analyzed the components which influence businesses and region capability to exploit information communication technologies to develop.
\end{abstract}

Keywords: network economy, electronic services, the network readiness of the enterprises

JEL Classification: R13, M20, K30

Received: 4 April 2021

Accepted: 12 May 2021 


\section{Introduction.}

\subsection{Relevance of the topic and problem statement.}

Enterprises' capability to take advantage of the network economy, readiness, and actual use remain the key factors and prerequisites for economic and social effect. The emergence of the information society based on the network economy is a strategically important task in building a competitive, dynamic state and its regions. Awareness of the issue is the first step that has already been taken. Significant measures have been taken to support the economy, which is knowledgebased and enables the development of the information society at the national and regional levels. Many actions need to be taken in the coming years in ICT development and their implementation in enterprise activities.

The growth of the network economy affects the economy as well as society. Social effects include shaping the innovation model of the expansion, enabling each person to fully realize their potential to ensure personal and social development and improve the quality of life. However, this cannot be achieved without firstly, an effective state policy; secondly, the participation of economic entities in the processes of information society forming by supporting and implementing regional and local initiatives; thirdly, shaping of the information infrastructure of a region and its integration with the global infrastructure.

Access and impact issues remain essential, especially for regions with slow economic growth and a significant digital divide. The latest technologies and the desired economic and social effect depend on the general environment - infrastructure, innovation environment, actual business readiness to use new data exchange opportunities.

Ukraine can be highly competitive. Economically the country can grow due to the exploitation of the network economy tools, primarily, the development of regional enterprises through information and communication technologies, a speed increase of broadband communication, online dissemination of knowledge and online promotion of goods and services.

The Gross Regional Product (GRP) is the primary indicator of the region's economic growth. Econometric modeling of the impact of the enterprise network readiness index on the change of GRP in individual regions will enable to project of the transformation of the economic potential (economic effect) of the region and the level of dependence between the selected indicators.

\subsection{Literature review.}

Recent decades have been marked by the emergence of much research on the rise of the network economy conducted by local and foreign scientists. Yet, there have been few attempts to study the enterprise network economy growth problem, the influence of electronic network forms of business on social-economic indices of the regional economic growth. The issue of ICTs and the Internet role in securing social-economic development of the regional enterprises, detecting the digital divide in the network economy growth of the region, as well as determining the objectives and mechanisms essential to reducing regional inequalities in the implementation and use of the new technologies by economic entities still needs to be tackled.

First studies that investigated the impact of the information and telecommunication technologies on business and the effect of the "information revolution" on the developed countries' economy were conducted in the 60-70s by western scholars Galbraith [10], Tofler [25], Drucker [7], Mahloop [15]. A considerable number of different perspectives on social-economic aspects of the informatization of society's economic life were deployed in the 90s.

The results of modern research of social-economic programs of the information technologies and their influence on the economic entities are profoundly reflected in Western scholars' works. These researches are mainly dedicated to analyzing the characteristic features of the Internet technologys' impact on the economy. In these publications, the current or instead expected economic situation is 
defined as:

- Information economy (Castells [2], Drucker [8]);

- Next Economy (Bradford, Froomkin [4]);

- New Economy (Henning [11]); Swan [23]);

- Digital Economy (Tapscott [24]);

- Network Economy (Kelly [13]) or Networked Economy (Status Report [21]);

- neuro network economy (Dyatlov [5]);

- The era of big data (Mayer-Schönberger [17]).

Significant theoretical and empirical material focuses on shaping ideas about the rise of the network economy in current conditions. However, authors found limited evidence of a holistic view of the network economy development process, changes in the organizational and production structure of an enterprise, the specifics of the network functioning principles of the economic entities and features of the domestic market environment in the economic literature. This hurts the development of the network economy concept, finding ways to transition, identifying the potential benefits and threats to the national economic system.

The network economy is often stated as the information economy, whose main factors and products are information and knowledge. In 1996 the famous researcher of the information society Castells [3] published his work "The rise of the network society, the information age: economy, society and culture", where he researched the "network economy" concept. Back in 1989, Castells [2] published "The Informational City: Information Technology, Economic Restructuring, and the Urban Regional Process", and in 1998 the author completed the three-volume fundamental work "Information Age: Economy, Society and Culture". In the first part of his trilogy, M. Castells conducted an in-depth analysis of current trends that enable the rise of the "network society". The author notes that a new type of economy has emerged in the world. He calls it information and global economy and identifies their distinguishing features and the interaction between them. Since information by its nature is a resource that knows no boundaries, M. Castells views the information age as an era of globalization. Thus, the network organizations are both the means and the result of the globalization of society.

According to Castells [3], at the source of network society genesis were historical processes. At the beginning of the 1970s, there was the coincidence of three major independent processes: the information and technological revolution; cultural and social movements of the 1960s and 1970s; crisis and restructuring of capitalism and statism.

The interaction between these processes and their afterreactions emerged a new form of social organisation, the network society; the new information global economy, and the new virtuality culture.

Approached from this angle, "the network economy" can be defined as a synthesis of the following four components: the information economy, the digital economy, the knowledge economy, the high-tech economy, which provide the conditions for developing a new, next economy. These four components are the areas that interact and complement each other. The knowledge economy facilitates intellectual property merchandise, information economy secures dissemination, high technology economy enables direct use and demand, digital economy means a transformation of all spheres of the economy through the transition of information resources and knowledge onto the computing platform for their further use exclusively (where possible) on this platform.

Authors prefer the term "network economy" because, in their opinion, this concept most clearly reflects current trends in social-economic development. After all, ICTs have invaded all areas of human activity.

The modern period in the development of mass media is based on the widespread use of Internet technologies and enables a new form of an economic organization called "information society". It is 
called "the network economy" or "network forms of activity organization" in terms of economy.

Network economy is a new science that has been given a variety of names. The approaches of scientists to defining the essence of the network economy can be summarized as follows:

- form of economic activity in the economy of horizontal relations (Kwilinski [14], Tsvilev [29], Parinov [19]);

- economy which is based on the use of Internet technologies (Dyatlov [6], Yunusov [16], Shkarlet [20], Dubyna [9]);

- economy, which is associated with the production and distribution of network goods (Bugorsky [1]; Strelets [22]).

The insufficient degree of development of theoretical and methodological approaches to the problem of emergence and growth of the network economy, the features of these processes in the context of global structural transformations cause the objective necessity of further investigation of this problem. Having analyzed different approaches to the definition of the term "the network economy", authors can conclude that today the terminology is not unequivocally defined. The researchers described this concept in various ways.

In our opinion, the essence of the network economy not only lies in the virtualization and implementation of a large number of business relations based on Internet technologies, but it also is primarily related to the evolution of global production and the development of network entities. Having analyzed different approaches to the definition of the term, authors agree with Castells, who understands the economy of a new type (network economy) as a synthesis of information and global economy, which is characterized by the development of information and communication networks and in which information flows play the critical role.

The concept of the network society and the network economy itself is a combination of concepts of the integration into the information and communication space, relying on social, cultural and economic characteristics that shape the global society.

\section{Research.}

\subsection{Network readiness analysis based on international indices.}

Ukrainian and western researchers have developed methods to determine the level of territorial readiness for the network economy. Since western developed countries are leaders in establishing an information society, methodological approaches analysis is a rating system based on the international indices and indicators. They enable characterizing fundamental changes, which are happening at the level of the national economy and business and are being influenced by modern information technologies; detecting patterns and trends of the new global information society; identifying effective management and decision-making tools in response to the challenges of the 21st century - a century of the information society, network economy and information technologies of enterprise management.

In this paper, the authors will evaluate existing methods of analyzing macro indicators and macro parameters of the development of network relations and measure the enterprises' readiness to exploit ICTs and their role in this process.

The most famous methods in our study are the measures of the following indices:

1. Global Competitiveness Index.

2. The ICT Development Index.

3. Networked Readiness Index:

3.1. Business and regulatory innovation environment: surrounding environment subindex;

3.2. E-readiness subindex;

3.3. Business usage: usage subindex; 


\subsection{Government usage: usage subindex.}

Figure 1 illustrates the dynamics of the critical indicators for the network readiness in Ukraine, namely: the Global Competitiveness Index (WEF), The ICT Development Index (ICT), and the WEF Networked Readiness Index. Since the number of participating countries has been changing, authors compared these indexes' measures, not their rankings.

Figure 1. The dynamics of indicators of the national economy network readiness in 2010-2018

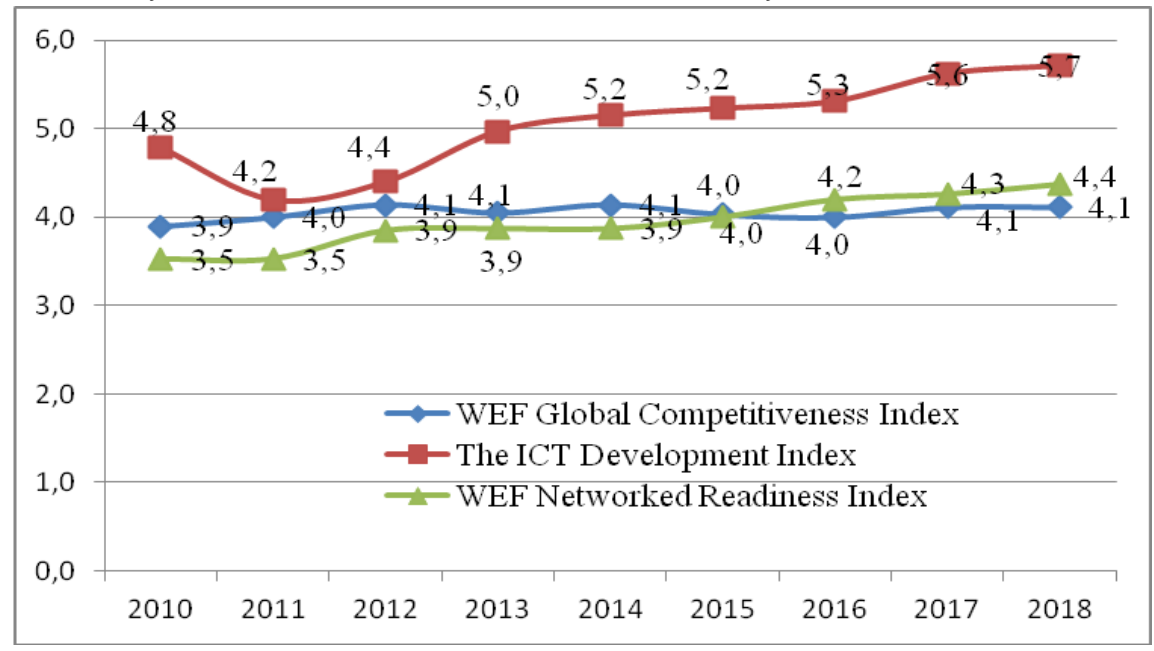

Source: World Economic Forum (WEF) [28], International Telecommunication Union (ITU) [12]

The change in indices measure allows us to trace relatively weak but positive dynamics in developing technologies of the network economy and the information society according to the presented international research methods. Throughout the eight years of the study, Ukraine did not demonstrate significant changes in the considered indices. The positive change in measures was primarily caused by the changes in methodology and economy, which are not supplemented by fundamental changes in the development of ICTs.

Thus, the primary conditions for developing the network economy tools in enterprises are building information and communication infrastructure and the legal framework for regulating relations in the ICT sector and its harmonization with international standards. Many adopted legal acts aimed at developing publicly available information infrastructure, information resources and access to telecommunication services and ICTs; promoting the diversity and quantity of e-services. While tackling the issue of global digital inequality, it is essential to comply with the Okinawa Charter of the Global Information Society (2000), the Geneva (2003) and Tunisia (2005) World Summits on the Information Society [18].

The global indices analysis of enterprises' network readiness confirms that ICTs facilitate economic growth and significantly impact the interaction of the state, business, and society. The network economy allows enterprises to use their potential and achieve their goals. However, the possibilities of access and the level of use of ICTs vary from state to state and nationwide.

\subsection{Methods and measurement of the network readiness of the enterprises in Ukraine.}

To determine the level of actual use of ICTs by enterprises at national and regional levels, authors need to analyze the network readiness at national and regional levels. The network economy's growth can be characterized by a whole set of indicators or criteria grouped according to specific characteristics. The authors used the State Statistics Service of Ukraine and the Central Statistics Office in the Chernivtsi region. Authors grouped the data into the following blocks: infrastructure and availability of digital content; business and innovation environment; business exploitation. There are quantitative, qualitative, functional and structure development indicators. Each of the 46 components of the network readiness of the enterprises is presented separately. However, it should be noted that they interact and supplement each other, but weaknesses in certain aspects negatively 
influence other indicators. Table 1 shows the detailed structure of the leading indicators of the enterprise network readiness index.

Table 1. Indicators used to measure the enterprise network readiness index

\begin{tabular}{|c|c|c|}
\hline № & Indicator & Block Name / Indicator description \\
\hline 1. & & Digital content infrastructure and accessibility \\
\hline 1.1. & $\mathrm{i}_{1}$ & Telephone holders (items per 100 inhabitants) \\
\hline 1.2. & $i_{2}$ & Mobile phones penetration rate (total population), $\%$ \\
\hline 1.3. & $i_{3}$ & Internet penetration rate (total population), \% \\
\hline 1.4 . & $\mathrm{i}_{4}$ & $\begin{array}{l}\text { Computers/PCs household penetration rate, \% (survey conducted by State Statistics } \\
\text { Committee every two years) }\end{array}$ \\
\hline 1.5. & $i_{5}$ & Percentage of mobile phone owners (total population), \% \\
\hline 1.6. & $\mathbf{i}_{1-5}$ & Aj1-length of NV. The arithmetic mean of the indices 1.1.-1.5 is calculated. \\
\hline 2 & & $\begin{array}{l}\text { Business and Innovation Environment } \\
\end{array}$ \\
\hline 2.1. & $i_{6}$ & Share of enterprises implementing innovations, $\%$ \\
\hline 2.2. & i $_{7}$ & $\begin{array}{l}\text { Share of foreign investments funds exploitation in the total cost of financing } \\
\text { innovative activities, } \%\end{array}$ \\
\hline 2.3. & $\mathrm{i}_{8}$ & $\begin{array}{l}\text { Share of capital investment in information and telecommunications, in } \% \text { of the total } \\
\text { sum }\end{array}$ \\
\hline 2.4. & $\mathrm{i}_{9}$ & $\begin{array}{l}\text { Share of enterprises in the field of information and communication, } \% \text { of the total } \\
\text { index }\end{array}$ \\
\hline 2.5. & $\mathrm{i}_{10}$ & $\begin{array}{l}\text { Share of enterprises making a profit in the field of information and } \\
\text { telecommunications, financial result before tax in\% of the total number of } \\
\text { enterprises }\end{array}$ \\
\hline 2.6. & $\mathfrak{i}_{11}$ & $\begin{array}{l}\text { Percentage of the employed population in information and telecommunications, } \% \text { of } \\
\text { total employed population }\end{array}$ \\
\hline 2.7. & $\mathrm{i}_{12}$ & $\begin{array}{l}\text { Percentage of the average monthly wage in the information and telecommunications } \\
\text { sector, \% of average monthly wage }\end{array}$ \\
\hline 2.8. & $\mathbf{i}_{13}$ & $\begin{array}{l}\text { Share of revenue from Internet access, \% of total revenue from mail and } \\
\text { communications services }\end{array}$ \\
\hline 2.9. & $\mathfrak{i}_{14}$ & $\begin{array}{l}\text { Share of revenue from mobile services, in \% of the total income from the sale of mail } \\
\text { and communication services. }\end{array}$ \\
\hline 2.10. & $\mathrm{i}_{15}$ & $\begin{array}{l}\text { Percentage of total exports of telecommunications, computer and information } \\
\text { services, \% of total exports of services }\end{array}$ \\
\hline 2.11. & I6-15 & Aj2-length of NV. The arithmetic means of the indices 2.1-2.11 are calculated. \\
\hline 3. & & $\begin{array}{c}\text { Business exploitation } \\
\end{array}$ \\
\hline 3.1. & $\mathrm{i}_{16}$ & Share of enterprises that used computers in the total number of enterprises, $\%$ \\
\hline 3.2. & $\mathbf{i}_{17}$ & $\begin{array}{l}\text { Share of enterprises that had Internet access in the total number of enterprises using } \\
\text { computers, \% }\end{array}$ \\
\hline 3.3. & $\mathrm{i}_{18}$ & Percentage of enterprises receiving banking and financial services via the Internet, \% \\
\hline 3.4. & $\mathrm{i}_{19}$ & Percentage of enterprises receiving education (training courses) via the Internet, \% \\
\hline 3.5. & $\mathrm{i}_{20}$ & Share of enterprises receiving information via the Internet, $\%$ \\
\hline 3.6. & $\mathrm{i}_{21}$ & Percentage of enterprises receiving online tax forms, \% \\
\hline 3.7. & $\mathrm{i}_{22}$ & Share of enterprises using the Internet to return/forward completed forms, \% \\
\hline 3.8. & $\mathrm{i}_{23}$ & $\begin{array}{l}\text { The proportion of enterprises using the Internet to perform administrative } \\
\text { procedures (declaration, registration, request for authorization), } \%\end{array}$ \\
\hline 3.9. & $\mathrm{i}_{24}$ & $\begin{array}{l}\text { The proportion of bidders within any electronic bidding system (e-procurement in } \\
\text { the system, not e-mail) }\end{array}$ \\
\hline 3.10. & $\mathrm{i}_{25}$ & $\begin{array}{l}\text { Percentage of enterprises having a website or homepage, \% of total surveyed } \\
\text { employees }\end{array}$ \\
\hline 3.11. & $\mathrm{i}_{26}$ & $\begin{array}{l}\text { Percentage of enterprises that have placed product catalogs or price lists on the } \\
\text { website, \% }\end{array}$ \\
\hline 3.12. & $\mathrm{i}_{27}$ & $\begin{array}{l}\text { The proportion of enterprises offering proposals to manufacture products according } \\
\text { to customer requirements or the opportunity for customers to independently design } \\
\text { products, \% }\end{array}$ \\
\hline 3.13. & $\mathrm{i}_{28}$ & Proportion of online reservations or bookings (add to cart), \% \\
\hline
\end{tabular}




\begin{tabular}{|c|c|c|}
\hline 3.14. & $\mathrm{i}_{29}$ & Share of enterprises making online payments, $\%$ \\
\hline 3.15. & $\mathrm{i}_{30}$ & $\begin{array}{l}\text { Percentage of enterprises providing personalized content within a website for regular } \\
\text { customers, \% }\end{array}$ \\
\hline 3.16. & $i_{31}$ & The proportion of enterprises that advertised job opportunities online, $\%$ \\
\hline 3.17. & $i_{32}$ & $\begin{array}{l}\text { The proportion of enterprises that used automated data exchange,\% of total } \\
\text { surveyed enterprises }\end{array}$ \\
\hline 3.18. & & of these enterprises that used automated data exchange for the following purposes: \\
\hline 3.19. & $\mathrm{i}_{33}$ & $\begin{array}{l}\text { The proportion of enterprises using automated data exchange to send orders to } \\
\text { suppliers, \% }\end{array}$ \\
\hline 3.20 . & $i_{34}$ & $\begin{array}{l}\text { The proportion of enterprises that used automated data exchange to obtain } \\
\text { electronic invoices, } \%\end{array}$ \\
\hline 3.21. & $\mathbf{i}_{35}$ & $\begin{array}{l}\text { Percentage of enterprises using automated data exchange to receive orders from } \\
\text { customers, \% }\end{array}$ \\
\hline 3.22. & $\mathrm{i}_{36}$ & $\begin{array}{l}\text { The proportion of enterprises using automated data exchange to send electronic } \\
\text { invoices, } \%\end{array}$ \\
\hline 3.23. & $\mathrm{i}_{37}$ & $\begin{array}{l}\text { Percentage of enterprises that used automated data exchange to send or receive } \\
\text { product information (product catalogs, press releases, etc.), \% }\end{array}$ \\
\hline 3.24 . & $\mathrm{i}_{38}$ & $\begin{array}{l}\text { The proportion of enterprises that used automated data exchange to send or receive } \\
\text { transport documents (invoices), \% }\end{array}$ \\
\hline 3.25 . & $\mathrm{I}_{39}$ & $\begin{array}{l}\text { Share of enterprises that used automated data exchange to provide payment orders } \\
\text { to financial institutions, } \%\end{array}$ \\
\hline \multirow[t]{2}{*}{3.26.} & $\mathrm{i}_{40}$ & $\begin{array}{l}\text { The proportion of enterprises that used automated data exchange to send or receive } \\
\text { data to/from government agencies (tax returns, statistical reporting, etc.), \% }\end{array}$ \\
\hline & & $\begin{array}{l}\text { The proportion of enterprises that used automated data exchange to determine the } \\
\text { level of technical equipment, production plans, or demand prognosis, } \%\end{array}$ \\
\hline 3.27. & $\mathrm{i}_{41}$ & with suppliers \\
\hline \multirow[t]{2}{*}{3.28.} & $\mathrm{i}_{42}$ & with customers \\
\hline & & $\begin{array}{l}\text { The proportion of enterprises using automated data exchange for delivery } \\
\text { development (delivery of raw materials or finished products),\%: }\end{array}$ \\
\hline 3.29 . & $\mathrm{i}_{43}$ & with suppliers \\
\hline \multirow[t]{2}{*}{3.30.} & $\mathrm{i}_{44}$ & with customers \\
\hline & & Percentage of enterprises that performed automated data exchange using $\%$ \\
\hline 3.31. & $\mathrm{i}_{45}$ & website (of the enterprise itself or a partner, or portals) \\
\hline 3.32. & $\mathrm{i}_{46}$ & automated data exchange (XML, EDIFACT, etc.) \\
\hline 3.33. & $\mathrm{i}_{16-46}$ & $\mathrm{Aj}_{3}$ - length of NV. The arithmetic mean of the indices 3.1.-3.33 is calculated. \\
\hline
\end{tabular}

The purpose of this analysis is to select indicators that reflect the network-readiness of regional enterprises from the ICTs exploitation, implementation of innovations, automated data exchange to present comparable data at national and regional levels. Since current network readiness growth and its determining factors are crucial to the economic process, authors grouped the selected indicators into three components to assess the potential of the enterprises' network readiness in the mediumand long-term perspectives.

To characterize the set of $\mathrm{n}$ parameters with one criterion - the Enterprise Network Readiness Index, authors introduce the concept of the network vector (NV) and its length (module) in ndimensional vector space $(\mathrm{Aj})$. In our paper, the authors use the methodology of the International Academy of Communications (IAC). It allows us to measure the total length of the vector of the network readiness of enterprises and in each block, to draw a graph of the NV scattering curves, to measure the digital divide indicator (DDI), to build a strategy for the development of the enterprise network economy mechanism.

$A j$ is a parameter of the $j$ - region, where the number of parameters $j$ varies from 1 to $n$, and the number of regions $\mathrm{j}$ changes from 1 to $\mathrm{N}$. In this case, authors will compare with the average indices nationwide, as well as with the maximum and minimum values regionally. Authors measure the length of the NV according to the following formula: 


$$
\mathrm{Aj}=\sqrt{\frac{1}{\mathrm{n}} \sum_{\mathrm{i}=1}^{\mathrm{n}} \mathrm{a}_{\mathrm{ij}}^{2}}
$$

The gap between the Chernivtsi region NV and the average values in Ukraine shows the digital measure of the difference in enterprises' network readiness at the regional and national levels.

$$
\mathrm{Cjk}=\sqrt{\frac{1}{\mathrm{n}} \sum_{\mathrm{i}=1}^{\mathrm{n}}\left(\mathrm{a}_{\mathrm{ij}}-\mathrm{a}_{\mathrm{ik}}\right)^{2}}
$$

Thus, these formulas enable us to reduce the set of parameters to the indices $\mathrm{Aj}$ and $\mathrm{CjK}$, which are used in measuring the network readiness of the regions and Ukraine as a whole.

The presented indicators are a set of different multi-parameter indices, enabling us to conduct objective and detailed research and compare the data with a similar index at the national or regional level.

Table 2 and Table 3 show the the network readiness indicators of the enterprises in the Chernivtsi region in 2010 and 2018.

Dynamics of infrastructure and digital content accessibility illustrates an increase in the following indicators: Internet penetration rate (total population) by 4.4 and 22 , computers/PCs household penetration rate by $22 \%$, percentage of mobile phone owners by $9.3 \%$. The downward trend is only in the first indicator in the table (telephone holders (items per 100 inhabitants) index decreased by 19 , mainly due to mobile phones' preference.

The network vector length (NV) - Aj1 increased by 12.7\%, indicating improvements in infrastructure and digital content during 2010 - 2018 in the Chernivtsi region. Cj1k - the NV gap between the Chernivtsi region and Ukraine increased by 6.2. The data illustrate an evident gap between this block of indicators and the pace of the development rate at the state level.

Table 2. Block 1. The network readiness indicators of the enterprises in the Chernivtsi region in 2010 and 2018 2010 2018

Dynamics during the

\begin{tabular}{|c|c|c|c|c|c|c|c|c|c|c|}
\hline 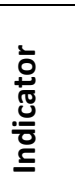 & 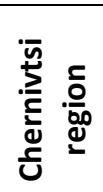 & 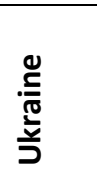 & 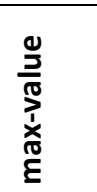 & 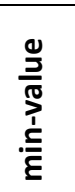 & 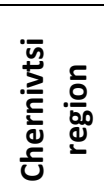 & 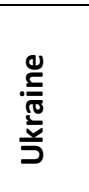 & 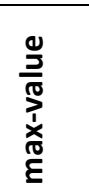 & 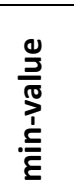 & Absolute device & $\begin{array}{l}\text { Relative } \\
\text { device }\end{array}$ \\
\hline $\mathbf{i}_{1}$ & 57 & 61 & 101 & 41 & 38.0 & 43.5 & 215.5 & 20.5 & -19.0 & 66.7 \\
\hline$i_{2}$ & 113.5 & 117.6 & 309.3 & 77.9 & 135.5 & 154.9 & 284.7 & 95.8 & 22.0 & 119.4 \\
\hline$i_{3}$ & 3.3 & 8.0 & 42.0 & 2.6 & 7.7 & 17.1 & 102.6 & 6.8 & 4.4 & 232.8 \\
\hline $\mathrm{i}_{4}$ & 20.2 & 25.0 & 50.4 & 12.5 & 42.2 & 43.0 & 45.6 & 33.6 & 22.0 & 208.9 \\
\hline$i_{5}$ & 82.2 & 84.2 & 92.6 & 78.5 & 91.5 & 97.4 & 98.8 & 93.3 & 9.3 & 111.3 \\
\hline$A j_{1}$ & 68.3 & 71.2 & 154.1 & 53.1 & 77.0 & 86.6 & 171.9 & 61.9 & 8.7 & 112.7 \\
\hline $\mathrm{Cj}_{1 \mathrm{k}}$ & 4.0 & - & - & - & 10.2 & - & - & - & 6.2 & 255 \\
\hline
\end{tabular}
period 2010-2018

Source: adapted from tables provided by the State Statistics Service of Ukraine 
Table 3. Block 2. The network readiness indices of the enterprises in Ukraine and Chernivtsi region in 2010 and 2018

\begin{tabular}{|c|c|c|c|c|c|c|c|c|c|c|}
\hline \multicolumn{5}{|c|}{2010} & \multicolumn{4}{|c|}{2018} & \multicolumn{2}{|c|}{$\begin{array}{c}\text { Dynamics during the } \\
\text { period } 2010-2018\end{array}$} \\
\hline 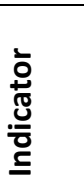 & 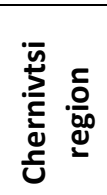 & $\begin{array}{l}\frac{\Phi}{\frac{\Phi}{\sigma}} \\
\frac{y}{\partial}\end{array}$ & $\begin{array}{l}\frac{0}{3} \\
\frac{1}{\pi} \\
\frac{1}{x} \\
0 \\
\frac{1}{\varepsilon}\end{array}$ & $\begin{array}{l}\frac{0}{2} \\
\frac{2}{10} \\
\frac{1}{E}\end{array}$ & 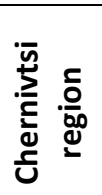 & $\begin{array}{l}\stackrel{0}{\frac{D}{\pi}} \\
\stackrel{\frac{2}{5}}{\supset}\end{array}$ & $\begin{array}{l}\frac{0}{3} \\
\frac{1}{\pi} \\
\frac{1}{x} \\
0 \\
\frac{1}{\varepsilon}\end{array}$ & $\begin{array}{l}\frac{0}{2} \\
\frac{1}{1} \\
\frac{1}{E} \\
\frac{5}{E}\end{array}$ & $\begin{array}{l}\text { Absolute } \\
\text { device }\end{array}$ & $\begin{array}{c}\text { Relative } \\
\text { device }\end{array}$ \\
\hline $\mathrm{i}_{6}$ & 11.3 & 11.5 & 21.9 & 9.2 & 14.1 & 15.5 & 23.3 & 5.7 & 2.8 & 124.3 \\
\hline$i_{7}$ & 0.0 & 30.0 & 98.8 & 0.0 & 0.0 & 0.5 & 26.9 & 0.0 & 0.0 & - \\
\hline $\mathrm{i}_{8}$ & 0.3 & 4.8 & 14.4 & 0.1 & 0.2 & 7.9 & 22.2 & 0.1 & -0.2 & 50.0 \\
\hline ì & н/д & н/д & н/д & н/д & 3.8 & 7.0 & 7.0 & 2.0 & - & - \\
\hline $\mathbf{i}_{10}$ & 73.1 & 59.0 & 76.2 & 50.0 & 71.5 & 73.9 & 85.7 & 72.6 & -1.6 & 97.8 \\
\hline $\mathrm{i}_{11}$ & н/д & н/д & H/д & н/д & 3.3 & 1.7 & 86.0 & 2.5 & - & - \\
\hline $\mathbf{i}_{12}$ & 118.2 & 141.2 & 146.4 & 110.9 & 84.5 & 173.3 & 220.7 & 73.1 & -33.7 & 71.5 \\
\hline$i_{13}$ & 7.6 & 8.0 & 12.6 & 2.8 & 9.0 & 12.1 & 35.9 & 4.4 & 1.4 & 118.8 \\
\hline $\mathfrak{i}_{14}$ & 55.6 & 60.8 & 80.9 & 42.2 & 66.2 & 59.1 & 79.5 & 48.5 & 10.6 & 119.1 \\
\hline $\mathbf{i}_{15}$ & н/д & н/д & н/д & н/д & 8.7 & 21.0 & 49.2 & 0.0 & - & - \\
\hline $\mathrm{Aj}_{2}$ & 56.8 & 63.5 & 79.6 & 48.8 & 36.5 & 57.5 & 80.9 & 31.4 & -20.3 & 64.3 \\
\hline $\mathrm{Cj}_{2 \mathrm{k}}$ & 15.5 & - & - & - & 30.7 & - & - & - & 15.2 & 198.1 \\
\hline
\end{tabular}

Source: adapted from tables provided by the State Statistics Service of Ukraine

Analysis of the Chernivtsi region's business and innovation environment showed that during the period 2010-2018, the share of enterprises implementing innovations was $11.3 \%$ and $14.1 \%$, respectively. It should be noted that there is a direct relationship between the size of the enterprise and its level of innovation since the implementation of innovations requires a certain number of employees involved in research and technological development. Consequently, the largest share of both technologically innovative and non-technologically innovative enterprises was among large enterprises. In 2018, this indicator's most significant value was recorded in the Kharkiv region enterprises $-23.3 \%$, and the smallest in the Transcarpathian region $-5.7 \%$.

In 2010-2018. There was no record of foreign investment funds exploitation in the total cost of financing innovative activities. Innovations were mainly funded by the enterprise itself, a small share of credit and budgetary funds.

The results of the analysis demonstrate the insufficient development of Ukrainian enterprises on an innovative basis. The main problems of business development in the region are: small and medium-sized enterprises financing difficulties; low investment and innovation activity of small business; uneven development of small and medium-sized enterprises in regional and territorial context (more than $65.0 \%$ of small enterprises are based in cities); decrease in credit loans, lack of working capital due to the high cost of loans.

Since the use of information and telecommunications is a priority in the network economy, authors selected a number of indicators that from our point of view are the main ones in the evaluation of this field: the absolute deviation of capital investment in information and telecommunications decreased by 0.2 ( 0.3 and $0.2 \%$ in 2010 and 2018 respectively); the share of enterprises in the field of information and communications, in \% of the total indicator for the region almost did not change during the study period (since in 2010 the index was not measured, authors analysed the data during the period 2011 - 2018, when the index ranged between 3.7 and 3.8\%); the index of the share of enterprises making profit in the field of information and telecommunications, financial result before tax in $\%$ of the total number of enterprises fluctuated within $73,1-71,5 \%$, percentage of employed population in information and telecommunications, $\%$ of total employed population decreased by 1,6 ; ranging between $3.9-3.3 \%$ and indicating negative dynamics during 2012 - 2018; the share of the average monthly wage in the sphere of information and telecommunications sector, in\% of the monthly average salary decreased by 33.7; a negative trend 
was observed throughout the study period; the share of revenue from Internet access, \% of total revenue from mail and communications services increased by $18.8 \%$; the percentage of income from mobile services, as a\% of total revenue from the sale of mail and communication services increased by $19.1 \%$; the share of total exports of telecommunications, computer and information services, $\%$ of total exports of services shows a negative dynamics for $2012-2018$, the index fluctuated within 14.7 $-8.7 \%$.

The length of the network vector (NV) - Aj2 decreased by 20.3, which is explained by the decrease in enterprises' innovation activity and insufficient development of information and telecommunications during2010 - 2018. Cj2k - the gap between NV of Chernivtsi region and Ukraine increased by $98.1 \%$, which also shows the negative dynamics of this block of indicators in the pace of the average development rate in Ukraine.

The analysis of Block 3 indicators "Business exploitation" during 2010-2018 shows positive changes in the table's data (Table 4). In 2018, among 622 enterprises in the Chernivtsi region that submitted their annual report No. 1-ICT, the share of enterprises that used computers in the total number of enterprises was almost $90 \%, 98 \%$ of which had access to the Internet.

A significant proportion of the enterprises studied used the following electronic services on the Internet:

$-84.3 \%$ received banking and financial services. Modern financial institutions provide a complex of services for the electronic management of their accounts via the Internet: account management (statements, transfers from account to account); currency, payment transactions (transfers of funds, payment of bills for goods, utilities, etc.); exchange of financial documents.

Table 4. Block 3 . The network readiness indices of the enterprises in Ukraine and Chernivtsi region in 2010 and 2018

\begin{tabular}{|c|c|c|c|c|c|c|c|c|c|c|c|}
\hline \multirow[b]{2}{*}{ 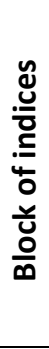 } & \multicolumn{5}{|c|}{2010} & \multicolumn{4}{|c|}{2018} & \multicolumn{2}{|c|}{$\begin{array}{l}\text { Dynamics during the period } \\
\qquad 2010-2018\end{array}$} \\
\hline & 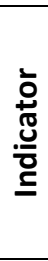 & 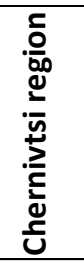 & 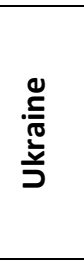 & $\begin{array}{l}\frac{0}{2} \\
\frac{\pi}{\pi} \\
\frac{1}{x} \\
\frac{1}{0} \\
\varepsilon\end{array}$ & 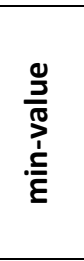 & 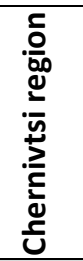 & $\begin{array}{l}\stackrel{0}{\frac{.}{T}} \\
\frac{\operatorname{s}}{\partial}\end{array}$ & $\begin{array}{l}\frac{0}{J} \\
\frac{D}{\pi} \\
\frac{1}{x} \\
\frac{1}{0} \\
\xi\end{array}$ & $\begin{array}{l}\frac{0}{2} \\
\frac{2}{N 1} \\
\frac{1}{E} \\
\frac{5}{E}\end{array}$ & $\begin{array}{l}\text { Absolute } \\
\text { device }\end{array}$ & $\begin{array}{l}\text { Relative } \\
\text { device }\end{array}$ \\
\hline \multirow{19}{*}{ 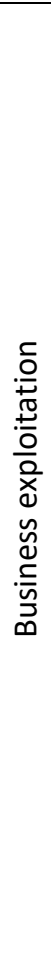 } & $\mathbf{i}_{16}$ & 79.2 & 87.7 & 92.6 & 79.2 & 94.0 & 98.1 & 103.7 & 76.8 & 14.8 & 118.7 \\
\hline & $\mathrm{i}_{17}$ & 78.8 & 86.2 & 89.0 & 78.8 & 98.0 & 103.6 & 105.5 & 98.3 & 19.2 & 124.4 \\
\hline & $\dot{\mathbf{i}}_{18}$ & 46.5 & 61.7 & 69.8 & 47.0 & 84.3 & 96.0 & 100.1 & 68.6 & 37.8 & 181.2 \\
\hline & $\mathrm{i}_{19}$ & 4.1 & 5.1 & 7.1 & 3.9 & 5.7 & 14.7 & 19.0 & -0.6 & 1.6 & 138.9 \\
\hline & $\mathrm{i}_{20}$ & 41.4 & 53.4 & 57.0 & 41.4 & 51.8 & 47.6 & 82.9 & 51.6 & 10.4 & 125.1 \\
\hline & $i_{21}$ & 36.9 & 51.2 & 53.9 & 36.9 & 85.2 & 95.9 & 108.1 & 71.1 & 48.3 & 230.9 \\
\hline & $i_{22}$ & 27.0 & 33.7 & 45.2 & 24.4 & 86.6 & 108.1 & 112.4 & 49.6 & 59.6 & 320.6 \\
\hline & $\dot{i}_{23}$ & 9.1 & 17.4 & 24.9 & 9.1 & 47.7 & 58.7 & 67.9 & 33.8 & 38.6 & 523.8 \\
\hline & $\dot{i}_{24}$ & 3.5 & 6.5 & 9.1 & 3.5 & 15.7 & 19.3 & 23.3 & 5.9 & 12.2 & 447.5 \\
\hline & $\dot{i}_{25}$ & 19.7 & 27.5 & 40.6 & 17.8 & 33.6 & 43.4 & 49.0 & 28.1 & 13.9 & 170.3 \\
\hline & $i_{26}$ & 12.1 & 19.2 & 27.1 & 11.3 & 22.3 & 27.0 & 36.1 & 17.9 & 10.2 & 184.6 \\
\hline & $\dot{i}_{27}$ & 6.1 & 7.9 & 11.2 & 4.9 & 8.2 & 11.0 & 17.8 & 6.0 & 2.1 & 134.8 \\
\hline & $i_{28}$ & 2.5 & 4.1 & 7.2 & 2.5 & 5.6 & 7.7 & 14.7 & 2.8 & 3.1 & 222.5 \\
\hline & $i_{29}$ & 2.4 & 5.8 & 8.0 & 2.4 & 6.6 & 7.9 & 18.6 & 1.8 & 4.2 & 274.3 \\
\hline & $i_{30}$ & 4.1 & 4.0 & 6.6 & 2.4 & 5.5 & 6.2 & 14.0 & 2.1 & 1.4 & 133.2 \\
\hline & $i_{31}$ & 3.2 & 5.8 & 11.9 & 2.5 & 6.4 & 10.0 & 24.2 & 3.2 & 3.2 & 200.4 \\
\hline & $i_{32}$ & 30.5 & 45.3 & 52.2 & 30.5 & 99.3 & 100.1 & 108.9 & 53.2 & 68.8 & 325.6 \\
\hline & $\dot{i}_{33}$ & 15.2 & 22.8 & 25.5 & 15.2 & 58.8 & 66.8 & 87.3 & 22.6 & 43.6 & 386.5 \\
\hline & $i_{34}$ & 18.0 & 26.1 & 30.3 & 18.0 & 79.3 & 83.3 & 99.9 & 31.5 & 61.3 & 440.6 \\
\hline
\end{tabular}




\begin{tabular}{ccccccccccc}
\hline $\mathrm{i}_{35}$ & 14.9 & 22.4 & 26.8 & 14.9 & 51.4 & 61.9 & 86.6 & 21.9 & 36.5 & 345.3 \\
\hline $\mathrm{i}_{36}$ & 13.1 & 21.5 & 25.2 & 13.1 & 53.8 & 68.0 & 87.4 & 27.4 & 40.7 & 410.8 \\
\hline $\mathrm{i}_{37}$ & 15.4 & 25.9 & 28.9 & 15.4 & 52.4 & 65.2 & 85.6 & 27.7 & 37.0 & 340.2 \\
\hline $\mathrm{i}_{38}$ & 8.6 & 11.0 & 12.6 & 8.6 & 35.9 & 40.7 & 93.7 & 15.8 & 27.3 & 417.7 \\
\hline $\mathrm{i}_{39}$ & 20.9 & 31.5 & 37.9 & 20.9 & 72.0 & 84.2 & 126.1 & 39.5 & 51.1 & 344.6 \\
\hline $\mathrm{i}_{40}$ & 20.5 & 31.4 & 42.1 & 20.5 & 96.8 & 97.9 & 124.0 & 49.3 & 76.3 & 472.3 \\
\hline $\mathrm{i}_{41}$ & 5.3 & 7.1 & 8.8 & 5.3 & 15.0 & 14.5 & 22.1 & 6.8 & 9.7 & 283.0 \\
\hline $\mathrm{i}_{42}$ & 4.1 & 6.6 & 20.5 & 4.1 & 13.5 & 13.0 & 15.3 & 5.9 & 9.4 & 329.1 \\
\hline $\mathrm{i}_{43}$ & 6.2 & 8.1 & 9.6 & 6.2 & 17.7 & 17.2 & 22.0 & 8.6 & 11.5 & 285.2 \\
\hline $\mathrm{i}_{44}$ & 5.3 & 7.5 & 9.1 & 5.3 & 15.4 & 15.3 & 21.7 & 7.1 & 10.1 & 291.0 \\
\hline $\mathrm{i}_{45}$ & 12.8 & 18.3 & 22.9 & 12.8 & 17.6 & 24.4 & 32.8 & 14.0 & 4.8 & 137.5 \\
\hline $\mathrm{i}_{46}$ & 24.8 & 25.8 & 44.7 & 23.4 & 89.8 & 105.9 & 122.7 & 22.5 & 65.0 & 362.3 \\
\hline $\mathrm{Aj}_{3}$ & 26.9 & 33.4 & 38.4 & 26.8 & 58.2 & 63.1 & 75.0 & 36.7 & 31.3 & 216.4 \\
\hline $\mathrm{C}_{3} \mathrm{k}$ & 7.6 & & & & 14.7 & & & & 14.8 & 118.7 \\
\hline
\end{tabular}

Source: adapted from tables provided by the State Statistics Service of Ukraine (2018)

$-85.2 \%$ received (tax) forms. The introduction of electronic digital signature in the electronic circulation of the country simplifies the work in accounting. There are currently many software products that allow you to form, sign, and report to virtually all authorities directly from the office. Moreover, it is possible to exchange tax invoices, send primary documents and more via the Internet;

$-86.6 \%$ used the Internet to return completed forms. The current level of the development of communication means allows to receive and return various forms of reporting, for this purpose, economic entities can use the services of offices of electronic services (https://kap.minjust.gov.ua), the portal of public services (https: // igov. org.ua);

- 99.3\% exchanged data automatically, enabling companies to improve management and control processes in manufacturing, procurement and supply. This also provides business partners with an effective tool for transferring information directly from one computer system to another, promotes efficiency and quality of business relations, and allows to eliminate a large number of paper documents;

$-96.8 \%$ used automated data exchange to send to or receive data from government agencies (tax returns, statistical reporting, etc.);

- 89.8\% automated data exchange (XML, EDIFACT, etc.). A large amount of paper documentation is created and processed in the business field, including purchase orders, invoices, catalogs, reports, payment orders, etc. In XML document exchange is based on transport protocols used on the Internet. With helping of the predefined tags, an object model of the data is defined, which is further filled with data and transmitted as an electronic document;

- 79.3\% used automated data exchange to receive electronic invoices. These are documents that certify the actual transportation of goods or the provision of services and their cost and can only be applied to VAT tax accounting. It is issued to the buyer (the customer) for two purposes: the first one is to record the fact that the order or work has been completed, the second - to confirm the amount of VAT paid so that it can then be deducted. You can receive an invoice by e-mail and use a cashless payment using various payment systems (Privat24, LiqPay, Savings 24/7, WebMoney and others), via the Internet;

$-72 \%$ used automated data exchange to send the requests for giro transfers (written approval of the account holder to transfer the corresponding amount from his/her account to the account of the payee).

Figure 2 shows the dynamics of the network vector Aj's indicators for the research period in the Chernivtsi region, compared with the average values in Ukraine, the maximum values recorded in the regions nationwide - the higher rate and the minimum values - the lower rate. Here authors can see that the NV length of the Chernivtsi region was growing at a relatively slow pace and had a negative 
slope in 2018. This curve tends to gravitate to the lower NV rates and does not exceed the average rates nationwide.

The regions with maximum values represent the higher rates of the network vector $\mathrm{Aj}$. The highest indices of the network readiness during 2010-2018 were observed in Kyiv, where were the highest mobile phones penetration rate and Internet penetration rate; computers/PCs household penetration rate and percentage of mobile phone owners; share of capital investments in information and telecommunications; share of enterprises in the field of information and communications; share of the employed population in the field of information and telecommunications; average monthly salary in the field of information and telecommunications; revenue from providing Internet access, exporting and importing telecommunications, computer and information services; the proportion of enterprises that used computers and had access to the Internet; share of enterprises with a website or homepage.

Figure 2. Dynamics of the network vector Aj during 2010-2018

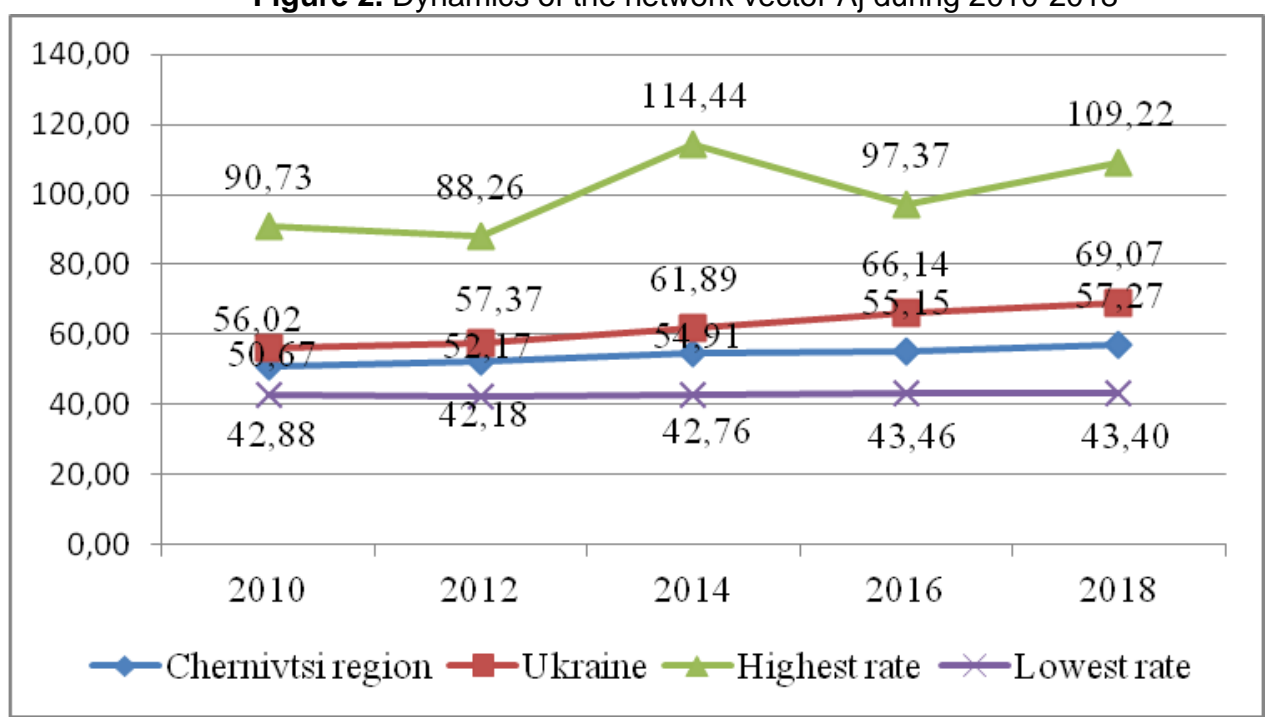

Source: developed by the authors

Regions with minimal values represent the lower rates of the network vector Aj. According to the analyzed indices, they were: Ternopil region - the lowest mobile phones penetration rate in Ukraine and revenue from mobile services; Chernivtsi - the lowest Internet penetration rate and percentage of mobile phone owners, average monthly salary in the sphere of information and telecommunications, the share of enterprises that used computers, the share of enterprises that had access to the Internet; Rivne - the lowest computers/PCs household penetration rate, export of services in the field of telecommunications, computer and information services; Transcarpathian the lowest share of enterprises implementing innovations, the percentage of enterprises that have a website or homepage; Lugansk region - the weakest indices of capital investment in information and telecommunications, the share of enterprises in the field of information and communications, the share of the employed population in the field of information and telecommunications, etc.

According to Figure 3 , the widest gap between the Chernivtsi region and Ukraine network vector was recorded in 2018, which indicates a negative tendency to increase the difference between the use of ICTs at the regional and national levels.

The analyzed indices of the Chernivtsi region enterprises' network readiness enabled us to measure the level of digital infrastructure, the business climate of the region, business opportunities provided by ICTs and the Internet, facilitating the implementation of procedures and their quantity. Having selected the network readiness indicators, the components that affect the ability of businesses and the region to exploit ICTs for their development were studied.

The indices show that infrastructure and digital content accessibility are vital to developing the network economy mechanism. The low technological readiness of the enterprises reduces the competitiveness of a region. The problems of low computer penetration rate, outdated equipment, 
insufficient investment in facilities and innovations, lack of high-quality Internet access, and the issue of human resources and digital skills remain acute. The gap between the lowest and the highest rates of the regions is quite significant.

Figure 3. Petal diagram of the Cjk length change - the gap between the NV of Chernivtsi region and Ukraine in 2010-2018

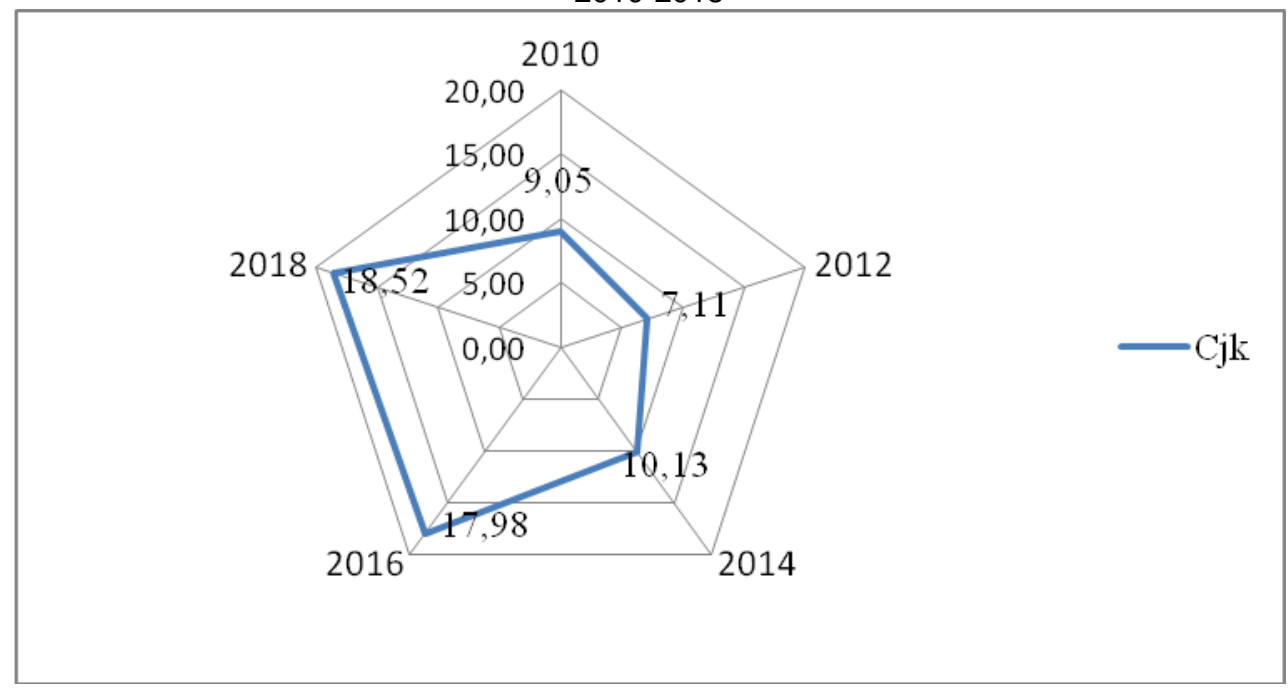

Source: developed by the authors

Significant gaps reduce the competitiveness potential of the regions, technological readiness, market size and the level of infrastructure development widen the gap between the regions.

\subsection{Methods and models of regression analysis.}

Regression analysis methods and models are central to the mathematical apparatus of econometrics. The purpose of this regression analysis is to determine the form of dependence between the variables $\mathrm{Aj}$ - the network vector of the development of enterprises in Ukraine and GRP (gross regional product) of Chernivtsi region, the estimate of the regression function, the estimation of unknown values (predicted values) of the dependent variable.

The regression analysis considers the one-sided dependence of the random variable $Y$ (GRP) on one non-random independent variable $X(\mathrm{Aj})$. In this case, the dependent variable $Y$ is also called a response function, an explanatory, endogenous variable, an effective trait, and the independent variable $\mathrm{X}$ is called an explanatory, exogenous variable.

$$
\mathrm{Mx}(\mathrm{Y})=\phi(\mathrm{x})
$$

This equation is called the regression equation, the function $\phi(x)$ is the regression function, and its graph is the regression line. It is used if the task is to determine or estimate the dependence of the explanatory variable $Y$ on one factor (explanatory variable) $X$. Thus, the input data are two sets of values (vectors) $x=(x 1, \ldots, x n)$ and $y=(y 1, \ldots, y n)$.

Excel's Analysis Pack calculates linear regression model parameters. The calculations for this model are shown in Figure 4.

The correlation coefficient value is 0.923 , which suggests a high degree of direct linear relations between the network readiness and GRP during the study period. R-squared (the coefficient of determination received) is 0,852 , or $85,2 \%$. This means that the calculated parameters $85,2 \%$ of the model explain the relations between the studied parameters. The normalized R-squared is 0,815 (the coefficient of determination is adjusted to the sample size). 
Figure 4. The results of the regression analysis of the impact of the enterprise network readiness index on GRP

\begin{tabular}{lr}
\multicolumn{2}{c}{ (gross regional product) } \\
\hline \multicolumn{2}{c}{ Regression statistics } \\
\hline Multiple R & 0.923106315 \\
R-squared & 0.852125268 \\
Standard R-squared & 0.815156585 \\
Standard error & 1256.406423 \\
Experimental observation & 6 \\
\hline
\end{tabular}

Analysis of variance

\begin{tabular}{lccrrr}
\hline & $d \boldsymbol{f}$ & SS & MS & $\boldsymbol{F}$ & Significance $\boldsymbol{F}$ \\
\hline Regression & 1 & 36385618.43 & 36385618.43 & 23.04992226 & 0.008641636 \\
Excess & 4 & 6314228.399 & 1578557.1 & & \\
Total & 5 & 42699846.83 & & & \\
\hline
\end{tabular}

\begin{tabular}{lcccccccc}
\hline & Coefficients & $\begin{array}{c}\text { Standard } \\
\text { error }\end{array}$ & $\begin{array}{c}\text { t- } \\
\text { statistics }\end{array}$ & $\begin{array}{c}\text { P- } \\
\text { Value }\end{array}$ & Lower 95\% & $\begin{array}{c}\text { Upper } \\
\mathbf{9 5 \%}\end{array}$ & $\begin{array}{c}\text { Lower } \\
\mathbf{9 5 . 0 \%}\end{array}$ & $\begin{array}{c}\text { Upper } \\
\mathbf{9 5 . 0 \%}\end{array}$ \\
\hline Y- & & & & & & & & \\
intersection & -63445.74159 & 16081.57725 & -3.945243716 & 0.016885265 & -108095.358 & -18796.1 & -108095 & -18796.1 \\
Variable X 1 & 1456.709113 & 303.4157387 & 4.801033458 & 0.008641636 & 614.2919707 & 2299.126 & 614.292 & 2299.126 \\
\hline
\end{tabular}

\begin{tabular}{ccccr} 
Calculation of residue & & & \\
\hline Observation & & Estimated $\boldsymbol{Y}$ & Residue & Standard Residue \\
\hline 1 & 10363.67573 & -471.675734 & -0.419728436 \\
2 & 11457.52997 & 511.4700257 & 0.455140043 \\
& 3 & 12551.38421 & 614.6157856 & 0.546925999 \\
4 & 14543.70768 & -786.707683 & -0.700064814 \\
5 & 16536.03115 & -1487.03115 & -1.323259209 \\
6 & 16886.67124 & 1619.328757 & 1.440986417 \\
\hline
\end{tabular}

Source: developed by the authors

In the dispersion Figure 4, in the column SS are sums of squares, in the column df - the number of degrees of freedom, in the column MS - the dispersion. The regression row in column $f$ shows the criterion statistics' value to check the significance of the regression. This value is calculated as the ratio of regression variance to residual. In column $F$, the authors estimated the probability of the value obtained by the criterion statistics. Since in this case, this value $=0.008$, which is less than 0.05 (of the given level of significance), authors can conclude that the regression equation (dependence) is significant with a probability of $95 \%$ (the hypothesis that all coefficients of the regression function are zero is rejected).

In the coefficient row, the $y$-intersection is63445,7 estimates $Y$ value if all the variables in this model are equal to 0 . It means that the analyzed parameter values are also influenced by other factors not described in the model. The coefficient of 1456,709 shows the influence of the variable $X$ on $\mathrm{Y}$. This means that the enterprise network readiness index within this model influences GRP by 1456,709 . It is an effect with a "+" sign that shows a direct dependence between the indicators.

The standard error column calculates the standard deviations of the coefficients. The t-statistic column records the ratio of the coefficient values to their standard deviations. It is the value of criterion statistics to test the hypotheses about the significance of regression coefficients. The Pvalues column calculates the levels of significance corresponding to the values of the criterion statistics. It means that the estimated level of significance is less than the given level of significance 
(0.05), so the hypothesis about the significant difference of the coefficient from zero is accepted. The lower $95 \%$ and upper $95 \%$ columns indicate the confidence intervals with a confidence level of 0.95 .

The table Calculation of Residue in the observation column lists the ordinal numbers of the variable $Y$ values, and the column estimated $Y$ calculates the values of the regression function $y^{\wedge} x=f$ $(x)$. The residue column contains deviations of the actual data from the theoretical data $\left(y-y x^{\wedge}\right)$. The magnitude of these deviations underlies the calculation of the residual variance. Therefore, there is some scattering of the correlation field's points concerning the regression line, which is caused by other factors that are not taken into account in the regression equation.

The authors obtained an analytical dependence of the explanatory variable $Y$ on the explanatory variable $x$, which corresponds to Aj and GRP's original data. Thus, pairwise regression is a regression between two variables $-y$ and $x$, and the model $y=f^{\wedge}(x)$ has the form:

$$
y^{\wedge}=-63445,7+1456,709 x
$$

$y$ is the dependent variable (resultant trait);

$x$ - independent, or explanatory, variable (factor trait).

The sign " $\wedge$ " means that there is no strict functional dependence between the variables $x$ and $y$, so in virtually every case, the value of $y$ consists of two additions: $y=y^{\wedge} x+\varepsilon$,

where $y$ is the actual value of the resultant trait;

$y x$ is the theoretical value of the resultant trait found based on the regression equation;

$\varepsilon$ is a random variable characterizing the deviation of the resultant trait's real value from the theoretical found by the regression equation.

The random variable $\varepsilon$ is also called perturbation. It includes the influence of factors excluded from the model, random errors, and measurement features.

\section{Discussion of empirical findings.}

The regression coefficient is of great practical importance, for example, concerning the estimate of changes in the GRP performance indicator, depending on the change of factor-network readiness.

The regression coefficient is also used to determine the elasticity index. The coefficient of elasticity (KE) characterizes the percentage of change in the resultant indicator in case of change of the factor-trait by one percent.

Consequently, the authors can talk about the elasticity of GRP concerning the network vector. If there is a dependence of the $y$ value on $x$ value, then the formula for determining the elasticity of the exponent $\mathrm{y}$ is:

$$
\mathrm{K}_{\mathrm{E}}=\frac{\frac{\mathrm{dy}}{y}}{\frac{\mathrm{dx}}{\mathrm{x}}}=\frac{\mathrm{dy}}{\mathrm{dx}} \times \frac{\mathrm{x}}{\mathrm{y}}
$$

To find the average value of the GRP elasticity coefficient, the authors use the regression equation. If the value is calculated in the linear regression equation, the formula is:

$$
\mathrm{K}_{\mathrm{E}}=\mathrm{a}_{1} \frac{\mathrm{x}}{\mathrm{y}^{-}}
$$

To find the coefficient of elasticity, it is necessary to multiply the coefficient of regression a1 by the relation $\frac{x}{y^{-}}$, where $x$ is the average value of $A j$, and $A_{j}$, a $y^{-}-$GRP calculated by the regression equation for a given $\mathrm{Aj}$.

The average coefficient of elasticity was obtained by calculating this equation:

$$
\mathrm{K}_{\mathrm{E}(\mathrm{GRP})}=a_{1} \frac{x}{y^{-}}=1456,709 \times \frac{52,9748}{13723,2}=5,623243 .
$$

The estimate based on the constructed model is possible only if the model is adequate to the object - the original. The best way to test the model's adequacy is to compare the estimated and 
actual values, but in this case, the authors need to wait for the estimated period. During the estimate phase, model reliability can be measured with statistics. Using MAPE - mean absolute percent error - authors calculate how many percentages of the average theoretical levels (computed using the model) differ from the time series's actual levels.

$$
\text { MAPE }=\frac{\sum\left|\frac{Y_{i}^{\wedge}-Y_{i}}{Y_{i}}\right|}{n} * 100
$$

$\mathrm{n}$ is the number of levels in the time series;

$Y i$ is the $i$-th level of the time series;

$\hat{Y} i$ is the $i$-theoretical level of the time series.

The mean absolute percent error for our model is MAPE $=6.34 \%$ (see Table 5).

Table 5. Model adequacy calculation using MAPEMAPE

\begin{tabular}{cccccc}
\hline Observation & $\mathbf{Y}$ & $\hat{\mathbf{Y}} \mathbf{i}$ & $\hat{\mathbf{Y}} \mathbf{i}-\mathbf{Y i}$ & $(\hat{\mathbf{Y}} \mathbf{i}-\mathbf{Y i}) / \mathbf{Y i}$ & $|(\hat{\mathbf{Y}} \mathbf{i}-\mathbf{Y i}) / \mathbf{Y i}|$ \\
\hline 1 & 9892 & 10363.68 & 471.68 & 0.047683 & 0.047683 \\
\hline 2 & 11969 & 11457.53 & -511.47 & -0.042733 & 0.0427329 \\
\hline 3 & 13166 & 12551.38 & -614.62 & -0.046682 & 0.0466824 \\
\hline 4 & 13757 & 14543.71 & 786.71 & 0.057186 & 0.0571862 \\
\hline 5 & 15049 & 16536.03 & 1487.03 & 0.098813 & 0.0988125 \\
\hline 6 & 18506 & 16886.67 & -1619.3 & -0.087503 & 0.087503 \\
\hline & & & & & 6.3433318 \\
\hline
\end{tabular}

Source: developed by the authors

It illustrates that the theoretical levels (calculated on the model) deviate from the actual ones by $6.5 \%$ on average. The largest deviation was in 2015 , due to a significant increase in the price index and, accordingly, a nominal increase in GRP. Authors believe that a model with such a degree of accuracy allows us to make a fairly realistic estimate. Therefore, the authors conclude that it can be used in the analysis.

Considering goals and objectives, the regression equation's economic analysis showed that a $1 \%$ increase in the AJ network vector leads to a $5.62 \%$ increase in GRP. The equation shows positive relations between the considered indicators, which characterizes the stable, statistically significant nature of the network economy impact on the GRP of a region and confirms a causal link between the economic growth of the region and the development of the network economy throughout the investigated period of the development (2010-2018).

The main link between the network economy and economic growth is economic entities. Enterprises interested in achieving optimum activity and increasing turnover exploit the network economy by expanding their markets and creating the preconditions for boosting trade nationwide and abroad. It, in turn, becomes an impetus for the reorganization of production of goods and services and the recovery in the regional economy, creates incentives for investment growth and, consequently, leads to the growth of GRP.

To understand the essence of this phenomenon, the authors analyzed the effect of $A_{\jmath 3}$ on the turnover of Ukrainian enterprises. Calculation of the pair correlation coefficients between the indicators using CORREL in Excel shows a high degree of direct interdependence (0.97). According to the Business Exploitation block and a smaller degree of wholesaling (0.60), between retail turnover and the size of the network vector. 
Figure 5. Dynamics of the network vector $A j$ in 2010-2018. The effect of the retail turnover on the length of $A j 3$ nationwide

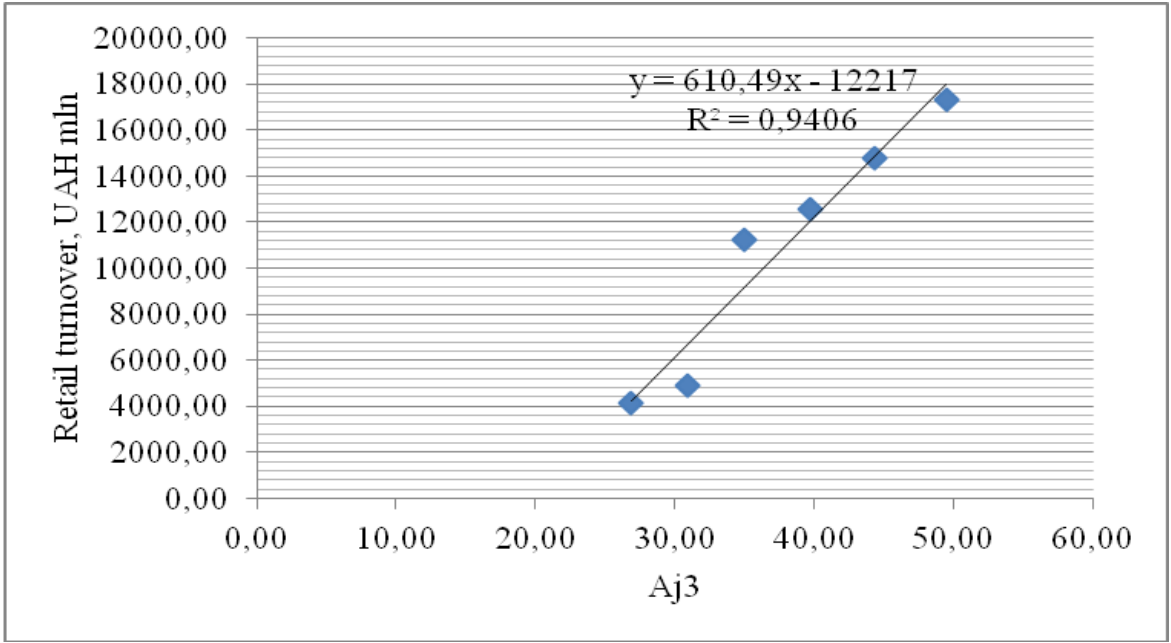

Source: developed by the authors

The average coefficient of elasticity between retail turnover and $A_{j 3}$ (ICTs exploitation by enterprises) was calculated with the regression equation: $y=610,49 x-12217$ (see Figure 5).

The authors calculated this equation substituting the average value of $A_{j 3}-37.73$.

$$
\mathrm{K}_{\mathrm{E} \text { (retail turnover) }}=a_{1} \frac{x}{y^{-}}=610,4 * \frac{37,73}{10813,392}=2,13
$$

\section{Conclusions.}

This study's results enabled identifying the weaknesses and competitive benefits of ICTs exploitation by enterprises, facilitating competitiveness, and setting vectors for national and regional network development. Also, the obtained results will be the basis for outlining the prospects for business development in the network economy, as one of the three factors that, in conjunction with the other two - government and society, determine the level of efficiency and well-being as a whole. Such interaction aims to outline priorities and facilitate information reforms and long-term programs for network economy development.

The results of economic effect (benefits) from the introduction of the network economy mechanisms can be divided into the following categories:

- GRP growth by $5.62 \%$ provided that the network vector is increased by $1 \%$;

- increase of retail turnover by $2.13 \%$ if the ICTs exploitation by enterprises increases by $1 \%$;

- enhancing the distribution and use of resources through marketing activities and the development of business models;

- product and process improvement through innovation, scientific research, consumer and seller feedback;

- management improvement through timely decisions and higher awareness.

\section{References}

1. Bugorsky, V. N. (2007). Network Economics: coursebook. Moscow.: Finance and statistics, p.256.

2. Castells, M. (1989). The Informational City: Information Technology, Economic Restructuring, and the Urban Regional Process, Oxford, UK; Cambridge, MA: Blackwell, p.353.

3. Castells, M. (2011). The rise of the network society, the information age: economy, society and culture, Cambridge, MA: Oxford, UK: Blackwell. p.656. 
4. De Long J. B., \& Froomkin, A. M. (1997). The Next Economy. Internet Publishing and Beyond: The Economics of Digital Information and Intellectual Property, edited by Deborah Hurley, Brian Kahin, and Hal Varian, Cambridge: MIT Press. (retrieved from

http://www.law.miami.edu/ froomkin/articles/newecon.htm).

5. Diatlov, S. A. (2000). The principles of information economy. Information Society. Vo. 2. pp.77-85.

6. Diatlov, S. A. (2008). Information and network economy: structure, dynamics, regulation: monograph, St. Petersburg: Asterion, p.416.

7. Drucker, P. F. (2002), Managing in the society, Butterworth-Heinemann, P.321

8. Druker, P. (2001). Beyond the information revolution, The Economist, Vo. 1. p.47-57.

9. Dubyna, M., Zhavoronok, A., Kudlaieva, N., \& Lopashchuk, I. (2021). Transformation of household credit behavior in the conditions of digitalization of the financial services market. Journal of Optimization in Industrial Engineering, 14(1), 97-102.

10.Galbraith, J. K. (1964), Economic Development, Harvard University Press, p. 109.

11.Henning, K. (2006), New Economy: forms of manifestation, cause and effect: monograph, K. Tucson, p. 306.

12.ITU Publications (retrieved from https://www.itu.int/ru/Pages/default.aspx).

13. Kelly, Kevin (1997). New rules for the new economy: 10 radical strategies for a connected world. Published by the Penguin Group Penguin Putnam Inc., New York, U.S.A. p. 179.

14.Kwilinski, A., Volynets, R., Berdnik, I., Holovko, M., \& Berzin, P. (2019). E-Commerce: Concept and Legal Regulation in Modern Economic Conditions. Journal of Legal, Ethical and Regulatory Issues, 22(SI2), 1544-0044-22-SI-2-357: 1-6. Retrieved from https://www.abacademies.org/articles/ECommerce-concept-and-legal-regulation-in-modern-economic-conditions-1544-0044-22-SI-2357.pdf

15.Machlup, F. (1967), Essays in Economic Semantics, The Norton library, №407. p.304

16.Matiushok, V. M. (1999). The Network Economy and Globalization of Economic Activity, Information Society, Vol. 6, pp. 46 - 47.

17.Mayer-Schönberger, V., \& Ramge, T. (2018). Reinventing Capitalism in the Age of Big Data. Avenue of the Americas, New York, p. 288.

18.Okinawa Charter on Global Information Societ (retrieved from https://www.mofa.go.jp/policy/economy/summit/2000/documents/charter.html).

19.Parinov, S. I. (1999). The third form of control for the network economy, Novosibirsk: IEEOPP SB RAS, (retrieved from http://www.ieie.nsc.ru/parinov/net-form.htm).

20.Shkarlet, S., Dubyna, M., Shtyrhun, K., \& Verbivska, L. (2020). Transformation of the Paradigm of the Economic Entities Development in Digital Economy. WSEAS transactions on environment and development, 16, 413-422.

21.Status Report on European Telework (1997). European Commission Report, 1997, (retrieved from http://www.eto. org.uk/twork/tw97eto).

22.Strelets, I. A. (2006). The Network Economy: coursebook, Moscow: Exmo, p.166.

23.Swan, M. (2015). Blockchain. Blueprint for a New Economy, Editor: Tim McGovern. Published by O'Reilly Media. Printed in the United States of America. p.123.

24.Tapscott, D. (1997). The digital economy: promise and peril in the age of networked intelligence. New York: McGraw-Hill (retrieved from https://archive.org/details/digitaleconomy00dont).

25.Toffler, A. (1981). The Third Wave, Pan Macmillan Limited, p. 543.

26.The Main Department of Statistics in Chernivtsi Region. (retrieved from http://www.cv.ukrstat.gov.ua/).

27.The State Statistics Service of Ukraine. (retrieved from http://www.ukrstat.gov.ua/). 
Economic and Legal Aspects of the Network Readiness of the Enterprises in Ukraine in the Context of Business Improving

28.The World Economic Forum. (retrieved from https://www.weforum.org/).

29.Tsvylev, R.I. (1996). Post-industrial development. Lessons for Russia. Moscow: Science, p.496. 